\title{
Flexural tests of masonry beam with and without reinforced bar
}

\author{
Ida Ayu Made Budiwati ${ }^{1, *}$ and I Ketut Sudarsana ${ }^{1}$ \\ ${ }^{1}$ Department of Civil Engineering, Universitas Udayana, Denpasar, Indonesia
}

\begin{abstract}
Behaviour of reinforced masonry has been studied experimentally to determine its strength potential. The increase in either compressive or tensile strength of masonry is possible due to the existence of rebar or wire mesh. The research is carried out to determine the effect of steel rebar on flexural strength of reinforced masonry beam using local brick. The square hollow masonry beams of $330 \times 330 \mathrm{~mm}$ with and without reinforced bar were tested in the laboratory to determine the load and deflection curves and bending strength. The rebar was located at the centre of beam's cross section and left unbounded. Mechanical properties of masonry's constitute were also determined. It was found that the flexural strength of beams with rebar of $22 \mathrm{~mm}$ diameter was greater 11 times than that of beam without rebar. However, that strength was only 1.6 times due to the weaker end connections of the beam to the rebar. Flexural strength of reinforced masonry beam with $22 \mathrm{~mm}$ rebar was greater 2.7 times compared to the beam using a rebar diameter of $16 \mathrm{~mm}$.
\end{abstract}

\section{Introduction}

Masonry is an element of a building structure consisting of clay brick or concrete block and mortar which are arranged in a specific pattern. The behavior of the masonry is similar to concrete that has a compressive strength far greater than its tensile strength. The masonry can similarly be reinforced with reinforcing steel to withstand or reduce the tensile load. Masonry with rebar is known as reinforced masonry while with prestressed high strength bar known as pre-tensioned or post-tensioned masonry. Both reinforced and pre-tensioned masonry are widely seen as building construction as well as arch bridges in the European region.

The use of reinforcing steel on the masonry's wall is enabled to withstand the tensile forces that occur on the walls and increase shear capacities of the wall [1]. The addition of reinforcing steel using steel wire or wire mesh can increase the compressive strength and flexural strength. Test results by Pascanawaty et al. [2] on brick walls with wire and wire mesh showed an increase in compressive strength of $95 \%$ and $65 \%$ respectively. Increased stiffness (EI) was also generated due to the addition of wire and wire mesh of 4 and 4.7 times respectively for masonry tested perpendicular to the bed joint and 6.5 and 9.2 times tested parallel to the bed joint. The pattern of failure occurring is seen to be caused by the

\footnotetext{
*Corresponding author: idabudiwati@gmail.com
} 
shear failure of the brick wall. The material properties of the masonry are affected by its constituent materials namely brick or block unit and mortar. Research by Budiwati [3] and Rahayu [4] has shown that the compressive stress of masonry prism is quite high once the better quality of brick unit and mortar are used.

The use of prestressed steel on columns made of brick walls can increase the natural frequency of columns. The $40 \mathrm{~mm}$ diameter prestressed steel was placed in the center of the hollow square column and was post-tensioned up to a maximum of $300 \mathrm{kN}$. Test results performed by Budiwati [5] in a short column of $1.325 \mathrm{~m}$ height showed an increase in the natural frequency from $55 \mathrm{rad} / \mathrm{s}$ to $75 \mathrm{rad} / \mathrm{s}(35 \%)$. The rise in frequency value is due to the presence of prestressed steel, as can be seen from the dominance of the resulting steel mode shape.

From the above description, it is generally seen that the portion of reinforcing steel or prestressing steel can improve the stiffness of structural elements. However, the resulting failure pattern of masonry is due to compressive strength. In order to study the effect of rebar on the flexural strength of masonry, the experimental research was conducted. Laboratory tests were carried out on clay brick masonry beams with rebar applied in the center of the hollow beam's cross-section and left unbonded. The result of bending beam test was in the form of load and deflection curve and crack pattern of the beam. From this research, the information related to the quality of clay brick walls and its component, bending strength of reinforced masonry beam, and cracked pattern of brick beam walls has been studied.

\section{Experimental works}

The research was conducted on four points bending test experimentally of four clay brick beams, three beams with rebar and one beam without rebar. Along with the beam testing, the component of masonry was also tested. They were the compressive test of brick, mortar, concrete, and masonry wallettes.

\subsection{Testing of masonry constituents'}

The testing of clay brick was conducted on ten brick units. The brick was measured its length, width, and thickness in accordance to SNI 15-0686-1989 [6]. The compressive test was conducted on those ten full-size bricks and also cube bricks of $70 \mathrm{~mm}$. Water absorption of the brick was also determined. The bricks were immersed in the water until saturated and left dry in the oven for one day. The brick mass was weight and used for calculation of water absorption.

Clay brick masonry wallettes were made to test the compressive and flexural strength of masonry. The compressive strength of the masonry wallettes was tested in accordance to SNI 03-4164-1996 [7] while for bending strength refers to the SNI 03-4165-1996 [8]. The tested specimens were prepared in the laboratory condition and tested at the age of 28 days.

\subsection{Testing of masonry beams}

Dimension and cross section of masonry beams is shown in Fig. 1. The total length of the beams was $1360 \mathrm{~mm}$ with the two ends connected to a concrete block of $50 \mathrm{~mm}$ thick. Beam cross section was $330 \times 330 \mathrm{~mm}$ and dimension of the hollow was $130 \times 130 \mathrm{~mm}$ (Fig 2b). The rebar was applied in the center of cross section (Fig 2a). Four beams (Fig. 2c) were constructed namely beam with no rebar (BR0), beam with rebar diameter of $22 \mathrm{~mm}$ (BR22), beam with rebar diameter of $16 \mathrm{~mm}$ (BR16), and beam with rebar diameter of 22 
with the slack connection (BR22S). The two point's load of $600 \mathrm{~mm}$ apart was applied in the middle length of the beams. The beams were loaded until failure and deflections at the center length were measured using dial gauges.

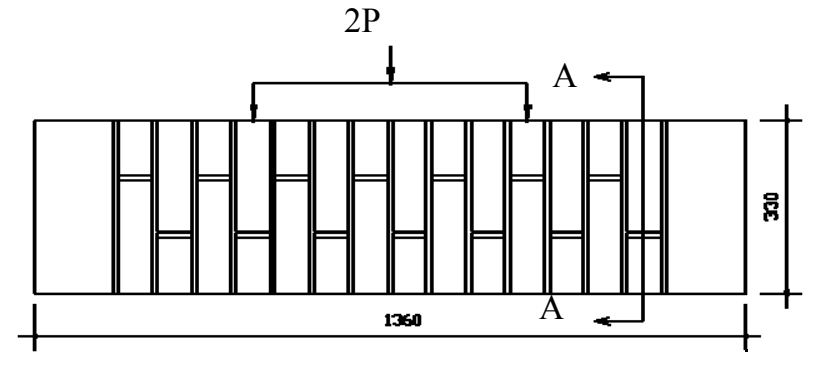

(a)

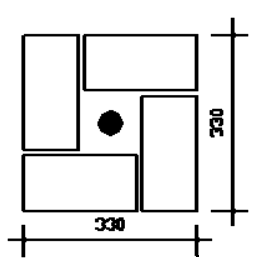

(b)

Fig. 1. Dimension of masonry beam (a) length of the beam, (b) cross section A-A.

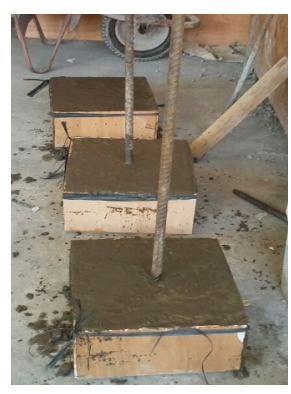

(a)

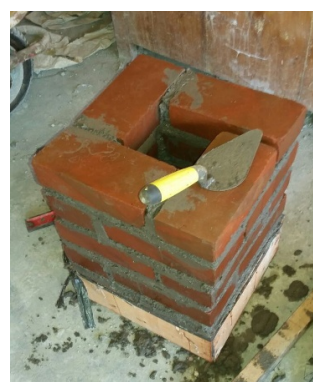

(b)

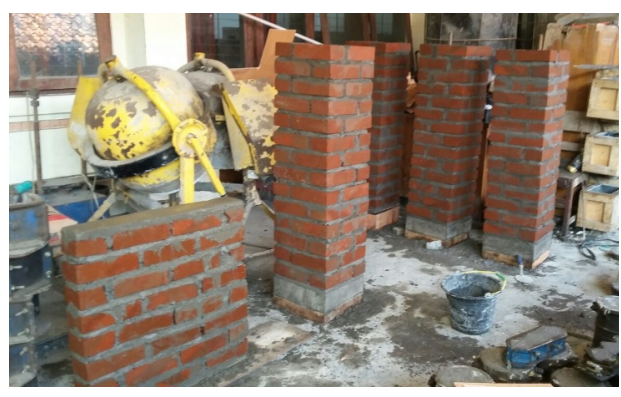

(c)

Fig. 2. Preparation of masonry wallette and beams (a) concrete casting dan rebar, (b) hollow beam cross section, (c) masonry wallette and beams.

\section{Results and discussion}

\subsection{Characteristic of masonry's components}

The red bricks being tested were from Darmasaba Village, Badung Regency. The average dimension of the brick was of $218 \mathrm{~mm}$ length, $102 \mathrm{~mm}$ width, and $63 \mathrm{~mm}$ thick. The average compressive strength value of the brick was $17.23 \mathrm{~N} / \mathrm{mm}^{2}$, and water absorption was $24 \%$. Standard deviation and coefficient of variation was 1.57 and $9 \%$. According to SNI 15-0686-1989 [6], the brick was characterized as class 50 (22\%), maximum standard water absorption requirements for bricks. The unit weight of the brick was $2.001 \mathrm{~kg} / \mathrm{m}^{3}$.

The compressive strength of the brick determined using $70 \mathrm{~mm}$ cube was $8.71 \mathrm{MPa}$, lower than the brick tested in full size. However, referring to SNI 15-0686-1989 [6] the value was above the lowest average compressive of $5 \mathrm{~N} / \mathrm{mm}^{2}$, according to Eurocode 6 [9] it meets the minimum average compressive strength of standard brick used as a structural wall of $2.5 \mathrm{~N} / \mathrm{mm}^{2}$, and it fits the minimum compressive strength brick that may be used according to the recommendation of Indonesia Earthquake Study [10] of $3 \mathrm{MPa}$.

The average compressive strength of the whole red brick $(219 \times 102 \times 63) \mathrm{mm}$ was 17.2 $\mathrm{N} / \mathrm{mm}^{2}$. The value is twice higher than the compressive strength of a $70 \mathrm{~mm}$ cube brick. 
The strength of the cube brick was tested in reference to the ASTM standard [11] while the whole brick refers to the SNI standard that is almost the same as the BS Standard [12]. Base on the two test results, it can be understood that the compressive strength of the brick is $8.71 \mathrm{~N} / \mathrm{mm}^{2}$ and is classified as Class K50.

The ratio of cement to the sand of the mortar used was 1:4. The average compressive strength of 10 mortars tested with a size of $40 \times 40 \times 40 \mathrm{~mm}$ was $22.30 \mathrm{~N} / \mathrm{mm}^{2}$. Regarding the compressive strength of the mortar, it is classified as class (i) according to BS 5628-1-1 1992 and M type mortar according to ASTM C 270 [11]. The concrete cap used in tested beam had an average compressive strength of $21.8 \mathrm{~N} / \mathrm{mm}^{2}$ tested using ten cylinders of 150 $\mathrm{mm}$ diameter and $300 \mathrm{~mm}$ height.

\subsection{Compressive and flexural strength of masonry}

The compressive test of masonry wallettes conducted in this study refers to the standard specified in SNI 03-4164-1996 [7]. The average maximum load applied was $92.5 \mathrm{kN}$ so that the average compression strength value of the masonry was $1.36 \mathrm{~N} / \mathrm{mm}^{2}$. The modulus of elasticity the masonry was of $327.3 \mathrm{~N} / \mathrm{mm}^{2}$, calculated as the modulus secant.

The compressive strength obtained was very small compared to the minimum strength in BS 5628-1-1992 [13] namely $3 \mathrm{~N} / \mathrm{mm}^{2}$ determined based on the brick and the mortar characteristic.

Flexural test conducted on the wallettes has a similar size to those used in the compressive test. Calculation of the results is referred to BS EN [14]. The average flexural strength of the masonry wallettes loaded parallel and perpendicular to the bed joint was $0.07 \mathrm{~N} / \mathrm{mm}^{2}$ and $0.62 \mathrm{~N} / \mathrm{mm}^{2}$ respectively. The strength of masonry tested perpendicular was higher than those tested parallel in which the flexural strength of the mas tested parallel was only $12 \%$ of those tested perpendicular. The crack occurred in the area between the brick and the mortar.

\subsection{Flexural tests}

Testing set up of the beams is shown in Fig. 4. Table 1 shows the loads and the corresponding flexural strength of the four masonry beams tested. The ratio of the flexural strength of each beam to BR0 is also given.

Table 1. Maximum load and flexural strength of the tested masonry beams.

\begin{tabular}{|c|c|c|c|}
\hline Spécimens & P (N) & f'lt (MPa) & Ratio to BR0 \\
\hline BR0 & 5,500 & 0.29 & 1.0 \\
\hline BR16 & 23,750 & 1.27 & 4.2 \\
\hline BR22 & 63,750 & 3.41 & 11.6 \\
\hline BR22S & 8,750 & 0.47 & 1.6 \\
\hline
\end{tabular}

The flexural strength obtained from the masonry beams with no bar (BR0) was of 0.29 $\mathrm{N} / \mathrm{mm}^{2}$. The presence of $22 \mathrm{~mm}$ diameter rebar at the cross section of the beam (BR22) resulted in a significant increase in the flexural strength of the beam to $3.41 \mathrm{~N} / \mathrm{mm}^{2}(11.6$ times). The significant increase is due to the rebar were cast to the concrete at both ends of the beam. From the table, it can be seen that by applying rebar diameter of $16 \mathrm{~mm}$ at the 
center of the beam's cross-section (BR16) bending strength obtained was $1.27 \mathrm{~N} / \mathrm{mm}^{2}$, increased 4.2 times compared to the beam without rebar (BR0). Bending strength of BR22 was 2.7 times bigger than BR16.

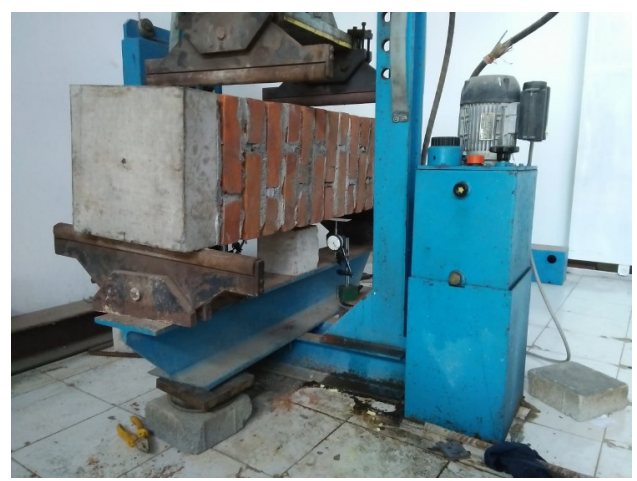

(a)

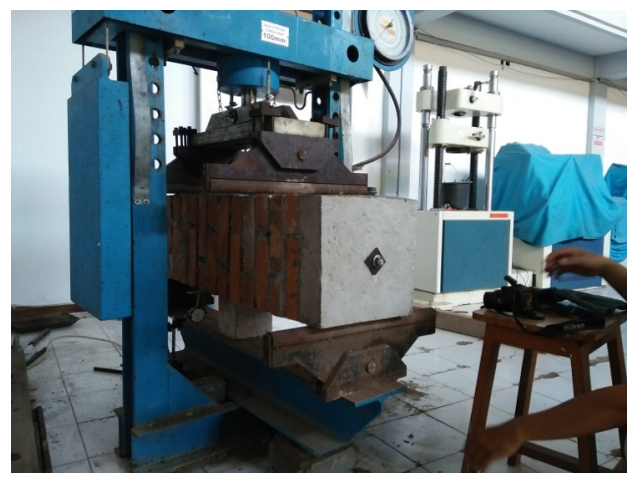

(b)

Fig. 3. Masonry beam (a) BR22S and (b) BR22) ready for testing.

The flexural strength of $0.47 \mathrm{~N} / \mathrm{mm}^{2}$ was found for the BR22S, the beams with slack rebar connection. The rebar was slotted into the hole of the center's beam cross section before testing and was washer-nut tightened. The value is 0.14 times smaller than the beam with the same rebar diameter, but it was cast in the concrete. However, the addition of the rebar increased the beam bending strength by 1.6 times compared to the non-rebar beam.

Load-deflection curves for all beams are shown in Fig. 4. Beam BR22 was the strongest compared to other three beams while BR0 was the weakest.

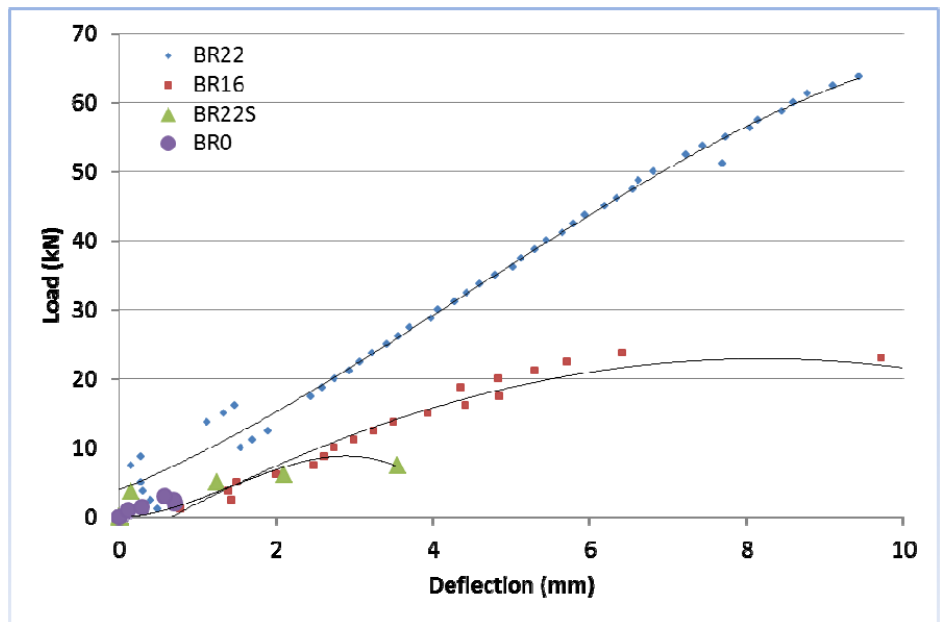

Fig. 4. Load deflections curves of the four testing beams.

The deflection occurring at the bottom side of the beam was recorded for every $1 \mathrm{kN}$ increment of the load applied. The load-deflection curve produced by the BR0 test specimen was the smallest of the four tested beams. The deflection occurring at the midspan of the BR0 beam was $0.7 \mathrm{~mm}$ with the maximum load applied was $5.5 \mathrm{kN}$. For BR16, maximum deflection was $10 \mathrm{~mm}$, and the corresponding load was $23.75 \mathrm{kN}$. There is an increase in the load capacity that can be withstood by the BR16 compared with the beam without a reinforced bar (BR0). From Fig. 2 the stiffness of the beam can be calculated, the average was 7,800 N/mm. Maximum loads and deflections of BR22 was $63.75 \mathrm{kN}$ and 9.6 
mm respectively, while for $\mathrm{BR} 22 \mathrm{~S}$ beam the maximum load was $8.75 \mathrm{kN}$ with the corresponding deflection of $4.0 \mathrm{~mm}$. It can be concluded that the effect of additional rebar in masonry beams is to increase the stiffness of the beam. The bigger the rebar diameter, the higher the strength of the beam is.

The pattern of bending collapse of masonry beam during loading is shown in Fig. 5. It can be seen that the position of masonry beam crack was on the pure bending area. A typical collapse pattern was a vertical crack parallel to the applied loading direction and formed a diagonal crack on the brick near the loading area. Due to the bed joint of masonry beam was parallel to the applied load, it was obvious to have the crack occurs at the area between brick and mortar that was indicated by the separation between the brick and the mortar. No bricks were broken, but it was only hair-crack in some area.

Crack patterns that occur in the beams did not change due to the difference in diameter of the reinforced bar used, including for beams with no rebar. The different bar diameter effect the maximum loads that caused the beams to fail.
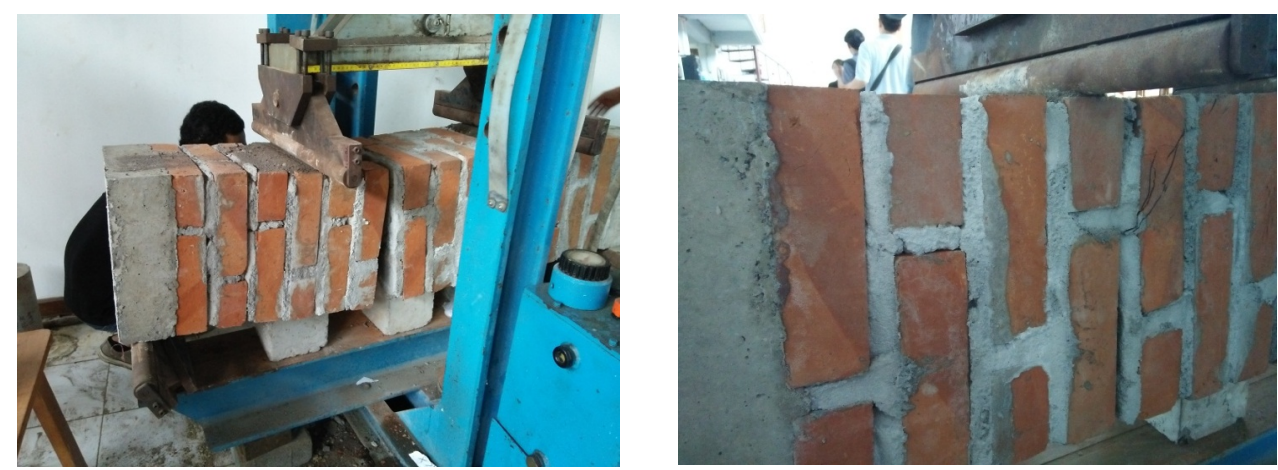

Fig. 5. Crack pattern of the masonry beam.

\section{Conclusions}

Based on results from the experimental study it can be concluded that the flexural strength of masonry beams is increased due to the existence of the rebar. The value of bending strength is $0.29 \mathrm{MPa}, 1.27 \mathrm{MPa}$, and $3.41 \mathrm{MPa}$ for a beam with no rebar (BR0), beam with rebar of $16 \mathrm{~mm}$ diameter (BR16), and beam with rebar of $22 \mathrm{~mm}$ diameter (BR22), respectively. The addition of reinforced bar on the beam resulted in a resilient strength increase of up to 11 times. However, if the reinforced bar is not installed well (BR22s), the growth is only 1.6 times compared to BR0. An increase in the diameter of reinforcing bars from $16 \mathrm{~mm}$ to $22 \mathrm{~mm}$ increases the flexural strength of 2.7 times.

Test results obtained for masonry beam material is the compressive strength of $8.71 \mathrm{~N} / \mathrm{mm}^{2}$ for brick, and $22.30 \mathrm{~N} / \mathrm{mm}^{2}$ obtained for mortar. Using those materials result in the compressive strength of masonry of $1.36 \mathrm{~N} / \mathrm{mm}^{2}$. The flexural strength obtained is 0.07 $\mathrm{N} / \mathrm{mm}^{2}$ and $0.62 \mathrm{~N} / \mathrm{mm}^{2}$ for masonry prism loaded parallel and perpendicular to the bed joint respectively.

Support from Magister Program of Civil Engineering Udayana University is gratefully acknowledged.

\section{References}

1. P. Agarwal, M. Shrikhande, Earthquake resistant design of structures (PHI Learning Pvt. Ltd, New Delhi, 2006) 
2. M.S. Pascanawaty, M. Sukrawa, I.A.M. Budiwati, Jurnal Spektran 4 (2016)

3. I.A.M. Budiwati, Jurnal Ilmiah Teknik Sipil, 13 (2009)

4. N.N.R. Rahayu, I.A.M. Budiwati, M. Sukrawa. Jurnal Spektran 4 (2016)

5. I.A.M. Budiwati, Dynamic interaction of post-tensioning bars and structural masonry columns (Thesis, The University of Manchester, Manchester, 2005)

6. Standar Nasional Indonesia, Mutu dan Cara Uji Bata Merah Berlubang SNI 15-06861989 (Badan Standardisasi Nasional, Jakarta, 1989)

7. Standar Nasional Indonesia, Metode Pengujian Kuat Tekan Dinding Pasangan Bata Merah di Laboratorium SNI 03-4164-1996 (Badan Standardisasi Nasional, Jakarta, 1996)

8. Standar Nasional Indonesia, Metode Pengujian Kuat Lentur Dinding Pasangan Bata Merah di Laboratorium SNI 03-4165-1996 (Badan Standardisasi Nasional, Jakarta, 1996)

9. CEN, Design of masonry structures reinforced and unreinforced masonry EN 1996-11 (European Committee of Standardization, London, 1996)

10. Indonesia Earthquake Study. Manual for Design of Normal Reinforced Concrete and Reinforced Masonry, Indonesia, (Indonesian Counterpart Team, 1981)

11. ASTM, Standard Specification for Mortar for Unit Masonry ASTM C 270 (ASTM International, West Conshohocken, 1989)

12. BSI, Specification for Clay Bricks BS 3921:1985, (British Standard Institution, London, 1985)

13. BSI, Code of Practice for use of masonry. Structural use of unreinforced masonry BS 5628-1-1992 (British Standard Institution, London,1992)

14. BSI, Methods of test for masonry. Determination of compressive strength BS EN 10521:1999 (British Standard Institution, London,1999) 